Fixed Point Theory, 18(2017), No. 2, 673-688

DOI 10.24193/fpt-ro.2017.2.54

http://www.math.ubbcluj.ro/ nodeacj/sfptcj.html

\title{
MULTIVALUED $\mathcal{R}_{\psi, \phi}$-WEAKLY CONTRACTIVE MAPPINGS IN ORDERED CONE METRIC SPACES WITH APPLICATIONS
}

\author{
NAYYAR MEHMOOD*, AKBAR AZAM** AND LJUBIŠA D.R. KOČINAC*** \\ ${ }^{*}$ Department of Mathematics and Statistics, International Islamic University \\ H-10 Islamabad, Pakistan \\ E-mail: nayyarmaths@gmail.com \\ ** Department of Mathematics, COMSATS Institute of Information Technology \\ Chak Shahzad, Islamabad 44000, Pakistan \\ E-mail: akbarazam@yahoo.com \\ ***University of Niš, Faculty of Sciences and Mathematics, 18000 Niš, Serbia \\ E-mail: lkocinac@gmail.com
}

\begin{abstract}
In this article we define multivalued $\mathcal{R}$-weakly contractive multi-valued mappings in ordered cone metric spaces without assumption of normality on cone, and generalize many results existing in the literature. We provide applications to solutions of integral inclusions and give nontrivial examples to support our main theorem.

Key Words and Phrases: Ordered cone metric space, multi-valued mapping, $\mathcal{R}$-weakly contractive mapping, differential inclusion.
\end{abstract}

2010 Mathematics Subject Classification: 47H10, 54H25.

Acknowledgements. The authors thank the referee for his/her careful reading of the paper and a number of remarks and suggestions which led to improvements on several places.

\section{REFERENCES}

[1] M. Abbas, A. Erduran, Common fixed point of g-approximative multivalued mapping in partially ordered metric space, Filomat, 27(2013), 1173-1182.

[2] R.P. Agarwal, M.A. El-Gebeily, D. O'Regan, Generalized contractions in partially ordered metric spaces, Applied Anal., 87(2008), 109-116.

[3] Ya.I. Alber, S. Guerre-Delabriere, Principles of weakly contractive maps in Hilbert spaces, new results in operator theory, Advances and Applications, (Eds. I. Gohberg, Yu. Lyubich), vol. 98, Birkhäuser Verlag, Basel, 1997, 7-22.

[4] I. Altun, B. Damjanović, D. Djorić, Fixed point and common fixed point theorems on ordered cone metric spaces, Applied Math. Lett., 23(2010), 310-316.

[5] I. Altun, G. Durmaz, Some fixed point theorems on ordered cone metric spaces, Rendiconti Circolo Matematico di Palermo, 58(2009), 319-325.

[6] M. Arshad, A. Azam, P. Vetro, Some common fixed point results in cone metric spaces, Fixed Point Theory Appl., 2009 (2009), Article ID 493965, 11 pages. 
[7] A. Azam, N. Mehmood, Multivalued fixed point theorems in tvs-cone metric spaces, Fixed Point Theory Appl., 2013(2013), 1-13.

[8] A. Belarbi, M. Benchohra, Existence theory for perturbed impulsive hyperbolic differential inclusions with variable times, J. Math. Anal. Appl., 327(2007), 1116-1129.

[9] K.C. Border, Fixed Point Theorems with Applications to Economics and Game Theory, Cambridge University Press, 1985.

[10] S.H. Cho, J.S. Bae, Fixed point theorems for multivalued maps in cone metric spaces, Fixed Point Theory Appl., 2011 (2011), Article ID 87, 7 pages.

[11] B.S. Choudhury, N. Metiya, Fixed point and common fixed point results in ordered cone metric spaces, Analele Ştiintifice ale Universităţii Ovidius Constanţa, Seria Matematica, 20(2012), $55-72$.

[12] A. Erduran, Common fixed point of g-approximative multivalued mapping in ordered partial metric space, Fixed Point Theory Appl., 2013(2013), Article 36, 14 pages.

[13] S.H. Hong, Fixed points of multivalued operators in ordered metric spaces with applications, Nonlinear Anal., 72(2010), 3929-3942.

[14] L. Huang, X. Zhang, Cone metric spaces and fixed point theorems of contractive mappings, J. Math. Anal. Appl., 332(2007), 1468-1476.

[15] S. Janković, Z. Kadelburg, S. Radenović, On cone metric spaces. A survey, Nonlinear Anal., 74(2011), 2591-2600.

[16] N. Mehmood, A. Azam, Lj.D.R. Kočinac, Multivalued fixed point results in cone metric spaces, Topology and Its Appl., 179(2015), 156-170.

[17] S.B. Nadler, Multivalued contraction mappings, Pacific J. Math., 30(1969), 475-488.

[18] A.C.M. Ran, M.C.B. Reurings, A fixed point theorem in partially ordered sets and some applications to matrix equations, Proc. Amer. Math. Soc., 132(2004), 1435-1443.

[19] Sh. Rezapour, R. Hamlbarani, Some notes on paper "Cone metric spaces and fixed point theorems of contractive mappings", J. Math. Anal. Appl., 345(2008), 719-724.

[20] W. Shatanawi, V.Ć. Rajić, S. Radenović, A. Al-Rawashdeh, Mizoguchi-Takahashi-type theorems in tvs-cone metric spaces, Fixed Point Theory Appl., 2012(2012), Article ID 106, 7 pages.

[21] M. Turinici, Abstract comparison principles and multivariable Gronwall-Bellman inequalities, J. Math. Anal. Appl., 117(1986), 100-127.

Received: September 30, 2014; Accepted: October 30, 2015. 